\title{
Effects of Chemical Constituents on Insect Pest Population in West African Okra, Abelmoschus
}

\author{
Adewusi, O.F ${ }^{1}$ And Oshipitan A.A ${ }^{2}$. \\ ${ }^{1}$ Department of Crop, Soil and Pest Management, Federal University of Technology Akure, Ondo State, Nigeria. \\ ${ }^{2}$ Department of Crop Protection, Federal University of Agriculture, Abeokuta, Ogun State, Nigeria.
}

\begin{abstract}
A study was carried out on the effects of chemical constituents on insect pest attack on genotypes in West African Okra, Abelmoschus caillei. The growth and yield response of the genotypes to pest infestation was determined. The biochemical analysis was carried out using the seeds of the genotypes to determine the bioactive ingredients content. Field experiment was laid out in Randomized Complete Block Design (RCBD) with four replications. The result indicated that three of the genotypes, (CEN 010, , NGAE-96-0123 and NGAE -96- 0067) attracted less number of insects, recorded lower percentage of leaf damage $(27.19 \%, 27.41 \%$ and $31.73 \%)$ and percentage pod damage (22.06\%, 35.68\% and $40.46 \%)$ and recorded higher level of harmful bioactive ingredients which conferred resistance to insect attack compared to the susceptible ones. The result of correlation analysis carried out between seed yield and the other traits show that a significant and positive exists between number of fruits per plant and number of damaged pods; number of insect feeding holes and number of Podagrica spp.; number of damaged pods and number of Dysdercus superstitiosus. A negative correlation also exists between number of damaged leaves, number of Dysdercus superstitiosus, number of insect feeding holes,number of Podagrica spp. and seed yield. From the study, it can be concluded that antixenosis was the basis of resistance to insect attack. Three of the genotypes (NGAE- 96-0067, NGAE-96-123 and CEN 010) used in this study are therefore recommended to farmers because of their economic value inspite of insect attack.
\end{abstract}

Key word: Abelmoschus caillei, chemical constituents, insect population, Dysdercus superstitiosus, Podagrica spp., Genotypes.

\section{Introduction}

West African okra, Abelmoschus caillei [A.chev] Stevels belongs to the family malvaceae. It is found throughout the high rainfall zones and is mainly grown for subsistence. Stevels (1988) described West African okra as a separate specie based on observation in Cameroon and on work carried out by Siemonsma in Cote d'Ivore between 1977 and 1980. A. caillei is mainly found in the humid coastal zones of west and central African and more sparingly in its savannah belt. It is much more abundant in the North of the Equator than the South of it. It is commonly found around homes and along roads (Ariyo, 1993) but rarely in undisturbed forests.

It is much appreciated because it continues fruiting during dry season when few other vegetables can be found thus providing the farmers with addition income. In contrast, the common okra, Abelmoschus esculentus [L] Moench fruits only during the rainy season or under irrigation. West African okra remains green during the period of drought, thus allowing people to eat its young leaves when needed. Since the identification of $A$. caillei as a second cultivated okra crop in Africa, there had been several germplasm collecting missions and the characteristic of the new specie is still being studied in detail. A. caillei is a multipurpose crop valued for its tender and delicious pods which are bigger than the pods of $A$. esculentus $(\mathrm{L})$ Moench.

Furthermore, the tender pods of okra at edible stage contains $88 \mathrm{ml} \mathrm{H}_{2} \mathrm{O}, 2.1 \mathrm{~g}$ protein, $0.2 \mathrm{~g}$ fat, $175.2 \mathrm{mg}$ minerals and $232.72 \mathrm{mg}$ vitamin in $100 \mathrm{~g}$ of edible portion; the edible leaves contain about $81 \mathrm{ml} \mathrm{H} 20,56$ calories of energy, $11 \mathrm{~g}$ carbohydrate, 4.4 protein, 0.6 fat, 2.1 fibre, $602.7 \mathrm{mg}$ mineral and $44.72 \mathrm{mg}$ vitamin per $100 \mathrm{~g}$ (FAO, 1972).As common to other crops, pest infestation on vegetables has negative effect on their yields. Over the year, pesticides have been used to control insect attack but this has always resulted in increased cost of production and sometimes having residual effect on the environments. Breeding programs that confer resistance to pest attack is needful in order to ensure food security. Plants show the resistance mechanism that deter the prevalent insects pests from inflicting on them any form of injury. Such resistance includes: Non-Preference (antixenosis) in which normal behavior is impaired to reduce chances of injury by pest specie. There is also the presence of morphological factors which affects the insects' penetration and such structure include: trichomes, glandular hair, gummy exudates, pubescence, tissue toughness or hardness.

\section{Insects Pest Of Okra And Their Economic Importance}

Yield of agricultural crops is often reduced below its potential because of pests and diseases. The control of these pests invariably results in increase yield but also increase in cost of production. It is often 
observed that most insecticides used in controlling pest population are not effective in totally eliminating the pest because additional pest may immigrate after application and some of the pest may even survive pesticide application. Thus, one practical means of achieving greater yields is to minimize the pest associated losses which are estimated at $14 \%$ of the total agricultural production. (Oerke et al, 1994).

Each crop has its own peculiar pest limiting its productivity. Insect pests not only cause direct loss to the agriculture products but also indirectly as vectors of various plant pathogens. Pests associated losses have been reported to be $52 \%$ in wheat, $83 \%$ in rice, $59 \%$ in maize, $74 \%$ in potato, $58 \%$ in soybean and $84 \%$ in cotton (Oerke et al, 1994).

Vegetable production which is an important source of income for many small scale farmers in African is also subjected to economic loss by insects pests. One major constraint in vegetable production is the effective prevention and control of pests and disease which causes high yield losses (Tindall, 1983). Vegetable losses due to pests can be as high as $25 \%$ which can result in severe income loss to small scale farmers. Avoidable losses in okra particularly due to pest have been placed at about 54\% (Chaudhary and Deedhack, 1989). Vegetable are attacked by large number of insect pest which ultimately lead to reduction in both quality and yield.

The pests limiting vegetables production are classified into the following broad categories: sapsucker, leaf eaters, leaf and fruit borers, leaf rollers, flower feeders and leaf miners.

Among the sapsuckers are the nymphs and adults of cotton aphid, Aphis gossypii which infest the plant by killing developing plant cells. Severally infested plant results in leaf distortion, curling and yellowing of leaves, stunted and retarted growth and failure to set bloom. It also acts as vector of viral disease (Tindall, 1983). Whiteflies, Bemisia tabaci (the adult lays eggs on the underside of the leaves and infested leaves become discolored and fall off from the plant). It also secret honeydew on plants which allow unsightly black sooty mould to grow resulting in reduced leaf area for photosynthesis. Severally infested plants have stunted and retarded growth and development. Green leaf hoppers, Empoasca spp. (feed on apices of young plant resulting in stunted and retarded growth, they also inhibit food translocation by destroying the tissues responsible for translocation (Hill, 1983); other include cotton stainers, Dysdercus superstitiosus and the cotton seed bug, Oxycarenus hyalinipennis.

The leaf eaters include beetles such as: Fleabeetles, Podagrica spp. (they make round holes in leaves resulting in death of young plants. In severe infestation the infested plants have retarded and stunted development which result in reduced plant vigor and an ultimate reduction in yield); Nisotra spp. (feed on the outer layer of leaves resulting in damage of the cotyledons. Severe infestation results in plant death); spiny boll worms, Earias spp. (They damage the young growing plants by boring through the terminal shoots resulting in death of the apical growth and the infested plants have stunted and retarded growth, (Tindall, 1983). Heliothis, Helicoverpa armigera (the pest) infest the growing plant by boring circular holes in the developing fruits and flower buds and the buds wither and fall off after being bored into (Hill and waller, 1994)).

The most devastating period of all insects pest is the larvae stage of the pest because the insects is at the growth stage and being highly active and effective, it is at this stage, their level of attack on growing plant has a detrimental effects on the growing plants and thus resulting in low yield. Based on this fact, it is expected that farmers should be able to recognize the insects found on their crops especially the commercial vegetable growers in order to put in place an adequate and effective pest control thus minimizing economic loss arising from reduction in yield.

\subsection{Breeding For Insect Resistance}

In the past, insecticides were used to combat the problem of pests. Nowadays, quite a number of farmers are still using insecticides but the fact remains that the consequential effects on the total income and returns is great because of the increase in cost of production. Not only this, continuous use of the insecticide has effects on the other beneficial insects and also contamination of the environment (Sun et al, 2000). The indiscriminate use of pesticides has been reported to have led to the destruction of beneficial insects and nontarget organisms, accumulation of toxic residues on produce and human poisoning (Kumar and Moorthy, 2001; Harris and Dent, 1999). Similarly, Awasthi (2001) reported that pesticides residues especially in vegetables may create health hazards to the consumers which in turn restrict export market of vegetables.

In recent years entomologists in several countries have stressed the need for developing integrated management strategies for insects control to optimize agricultural production without upsetting the balance of nature since massive application of pesticide result in adverse effects on the beneficial organisms, residual effect on crops and also environmental pollution. This has necessitated the use of target specific compound with low persistence and more emphasis should be based on integrated pest management which is based on host plant resistance to insect pests.

Plant breeders and entomologists should therefore, include insects' resistance as a component of their crop improvement program. With greater collaboration and commitment from plant breeders, biotechnologist and entomologists, crop resistance could play a major role in Integrated Pests' Management (IPM) of insect pest 
of crops. In many cases multiple genes are required for sustained resistance to counter pest adaptation, thus maintaining agricultural productivity to enhance world food security.

A thorough knowledge of insects, plants and their interrelationship is required to evaluate cultivar for insects' resistance. Successful breeding for insect and disease resistance has occurred in much type of crops including vegetables, fruits, field crops and ornamentals. Hence, selecting plants variety that has resistance or tolerance to insects or disease makes it possible to avoid or lessen the use of pesticides. When plants are attacked by insects, they defend themselves through a continuum of defensive strategies including direct resistance (chemical or mechanical traits that reduce the impact of the pests); indirect resistance (traits enhancing the action of enemies of the pests) or tolerance (regrowth). The site of production of defensive metabolites is variable in plants, depending on the nature of the compound and the plant species.

Several chemical constituents of plant serve as olfactory and gustatory stimuli for insects. These chemicals may be nutrients in form of sugar, amino-acid, phospholipids etc. or non-nutritive constituents that is, glycosides, alkaloids, terpenoids, etc. The insect may be repelled by plants volatile compounds without coming in contact with plant or having made contact, feeding may be suppressed or having bitten the leaf, the insects may be deterred from further feeding. A number of insects have been reported to be affected by the plant volatile compounds that are specific to their host plant (Visser, 1986). Zehnder (2004) reported that some plants contain organic compounds that act as pest repellents which protect the crops by keeping pests away from them and thus avoiding potential pest damages.

\section{Materials And Methods}

This research was carried out at the farm centre Federal Polytechnic Ilaro, Ogun State in February 2009. Six genotypes of West African Okra were utilized in this study. They were obtained from the germplasm collection of the National Centre for Genetic Resources and Biotechnology (NACGRAB), Moor Plantation, Ibadan.

Table 1: The Names and Sources of Okra Genotypes

\begin{tabular}{lll}
\hline \hline Parent No & Genotype name & Source \\
\hline \hline $\mathbf{P}_{\mathbf{1}}$ & NGAE-96-0060 & National Centre for \\
$\mathbf{P}_{\mathbf{5}}$ & NGAE-96-0066 & Genetic Resources \\
$\mathbf{P}_{\mathbf{6}}$ & NGAE-96-0067 & and Biotechnology (NACGRAB) \\
$\mathbf{P}_{\mathbf{8}}$ & NGAE-96-0123 & \\
$\mathbf{P}_{\mathbf{1 1}}$ & CEN 10 & \\
$\mathbf{P}_{\mathbf{1 2}}$ & OWOSDE & \\
\hline
\end{tabular}

The seed were sown in Feb. 2009 in a randomized completes block design using four replications each replicate measures $10 \mathrm{~m}$ by $7 \mathrm{~m}$. A single row plot with an inter row spacing of 1 metre was adopted. The spacing used was 1 meter between rows and 0.6 meter within rows. Two seeds were planted per hole and later thinned to one plant per stand. A maximum of 11 plants were maintained per row. A compound fertilizer of NPK 15:15:15 was applied at the rate of $50 \mathrm{~kg} / \mathrm{ha}$ in two doses, first at 3 weeks after planting and secondly at flowering. Data were recorded on six mid plants of each of the accessions. Weeding of the plot was done on a regular basis from planting to harvesting.

Data were collected on the following :- Number of leaves per plant, Number of damaged leaves per plant, Number of damaged pods per plant, Number of insects per plant, Number of pods per plant, Number of insects feeding holes per plant, ,Seed yield per plant and biochemical analysis of pods per plant.

\section{Results And Discussion}

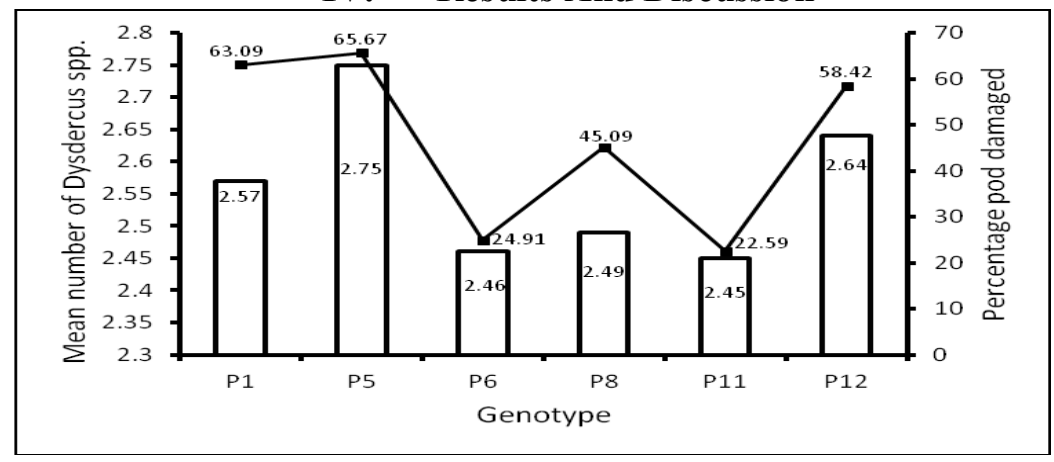

Figure 1: Population of Dysdercus spp. and Percentage of Pod Damaged Among The Genotypes Of West African Okra 
Figure 1 shows the population of Dysdercus superstitiosus and percentage of pod damaged among the genotypes of West African Okra. The result shows that genotype 5 was more susceptible to pod suckers recording the highest population of Dysdercus superstitiosus of mean 2.75 and highest percentage of pod damage of mean $65.67 \%$ while genotype 11 recorded the lowest population of mean 2.46 and lowest percentage of pod damage of mean $22.59 \%$ indicating that genotype 11 was more resistant to the attack of pod suckers.

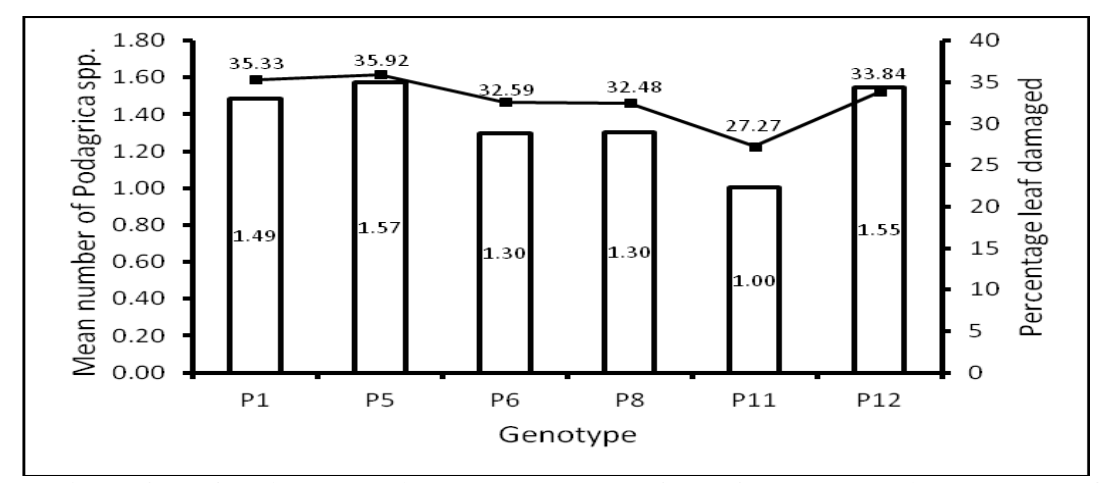

Figure 2: Population of Podagrica spp. And Percentage of Leaf Damaged Among The Genotypes Of West African Okra

Figure 2 shows the population of Podagrica spp. and percentage leaf damage among the genotypes of West African Okra. Genotype 5 recorded the highest population of Podagrica spp. of mean 1.57 while genotype 11 recorded the lowest population of Podagrica spp. of mean 1.00. The result shows that genotype 5 was more susceptible to Podagrica attack. Genotype 5 recorded the highest percentage of leaf damage of mean 35.92\% indicating that genotype 5 is more susceptible to Podagrica spp. while genotype 11 recorded the lowest percentage of mean $27.27 \%$ indicating that genotype 11 is more resistant to Podagrica spp. attack.

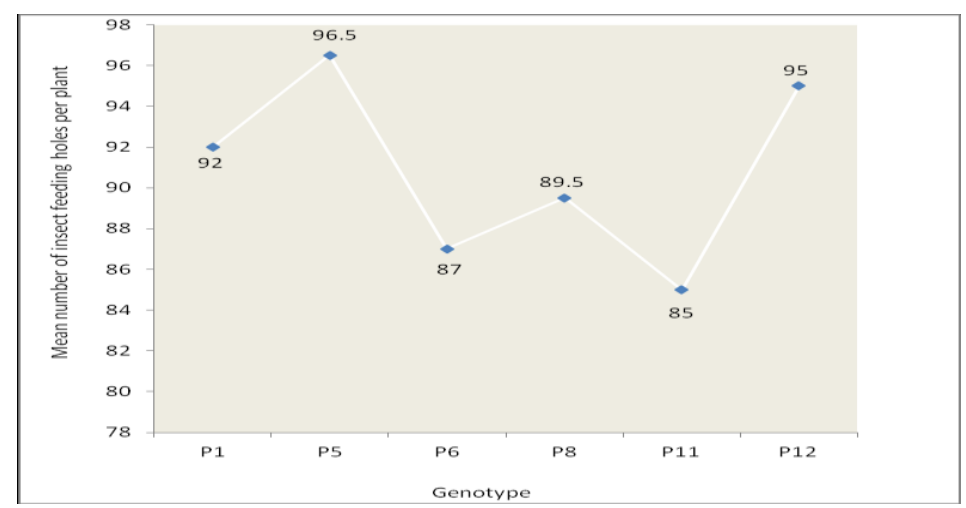

Figure 3: Number of Insect Feeding Holes per Plant Among The Genotypes Of West African Okra.

Figure 3 shows the number of insect feeding holes among the genotypes of West African Okra. Genotype 5 recorded the highest percentage of insect feeding holes per plant of mean $96.50 \%$ indicating that genotype 5 is more susceptible to Podagrica spp. While genotype 11 recorded the lowest percentage of mean $85.00 \%$ indicating that genotype 11 is more resistant to Podagrica spp. attack.

Table 2:- Seed Yield Per Plant Among the Genotypes of West African Okra.

\begin{tabular}{ll}
\hline Genotype & Seed yield per plant \\
\hline $\mathbf{P}_{\mathbf{1}}$ & 16.69 \\
$\mathbf{P}_{\mathbf{5}}$ & 12.90 \\
$\mathbf{P}_{\mathbf{6}}$ & 22.78 \\
$\mathbf{P}_{\mathbf{8}}$ & 21.26 \\
$\mathbf{P}_{\mathbf{1 1}}$ & 24.17 \\
$\mathbf{P}_{\mathbf{1 2}}$ & 18.20 \\
\hline
\end{tabular}

Table 2 shows the seed yield per plant among the genotypes West African Okra. Genotype 5 recorded the lowest seed yield of mean $12.90 \mathrm{~g}$ while genotype 11 recorded the highest seed yield of mean $24.17 \mathrm{~g}$. The result indicated that genotype 11 was more resistant to insect pests attack than the other genotypes and other Traits among the Genotypes of West Africa Okra. 
Table3: Correlation between Seed Yield

\begin{tabular}{|c|c|c|c|c|c|c|c|c|c|}
\hline & & NFP & NDP & NLP & NDLP & NDS & NIFH & NPS & SW \\
\hline \multirow{8}{*}{ P1 } & NFP & 1 & $0.555^{*}$ & 0.341 & -0.267 & 0.018 & -0.004 & 0.319 & 0.263 \\
\hline & NDP & & 1 & 0.033 & -0.084 & -0.200 & 0.218 & 0.378 & -0.128 \\
\hline & NLP & & & 1 & -0.162 & 0.267 & 0.133 & 0.043 & -0.030 \\
\hline & NDLP & & & & 1 & -0.038 & -0.301 & $0.525^{* *}$ & -0.050 \\
\hline & NDS & & & & & 1 & -.017 & -0.159 & -.0570 \\
\hline & NIFH & & & & & & 1 & $0.509^{*}$ & 0.168 \\
\hline & NPS & & & & & & & 1 & -0.035 \\
\hline & SW & & & & & & & & 1 \\
\hline \multirow{8}{*}{ P5 } & NFP & 1 & $0.429^{*}$ & 0.226 & 0.104 & 0.258 & 0.127 & $0.481^{*}$ & 0.308 \\
\hline & NDP & & 1 & 0.020 & 0.410 & 0.356 & 0.023 & $0.449^{*}$ & -0.215 \\
\hline & NLP & & & 1 & 0.171 & 0.230 & 0.294 & 0.297 & 0.272 \\
\hline & NDLP & & & & 1 & -0.097 & 0.064 & $0.442^{*}$ & 0.121 \\
\hline & NDS & & & & & 1 & -0.129 & 0.266 & $0.427^{-}$ \\
\hline & NIFH & & & & & & 1 & 0.163 & 0.120 \\
\hline & NPS & & & & & & & 1 & 0.152 \\
\hline & SW & & & & & & & & 1 \\
\hline \multirow{8}{*}{ P6 } & NFP & 1 & 0.392 & $0.483^{*}$ & -0.198 & -0.037 & $0.577^{*}$ & $0.434^{*}$ & $0.455^{*}$ \\
\hline & NDP & & 1 & 0.114 & -0.110 & -0.157 & 0.373 & -0.003 & 0.065 \\
\hline & NLP & & & 1 & -0.215 & -0.338 & $0.408^{*}$ & 0.340 & $0.563^{*}$ \\
\hline & NDLP & & & & 1 & 0.261 & -0.151 & -0.034 & 0.027 \\
\hline & NDS & & & & & 1 & -0.136 & 0.003 & -0.010 \\
\hline & NIFH & & & & & & 1 & 0.396 & 0.317 \\
\hline & NPS & & & & & & & 1 & 0.032 \\
\hline & SW & & & & & & & & 1 \\
\hline \multirow{8}{*}{ P8 } & NFP & 1 & $0.908^{*}$ & $0.720^{*}$ & -0.172 & 0.339 & -0.031 & -0.018 & 0.303 \\
\hline & NDP & & 1 & $0.702_{*}^{*}$ & -0.181 & 0.200 & -0.052 & -0.013 & 0.288 \\
\hline & NLP & & & 1 & -0.185 & 0.417 & -0.244 & -0.095 & 0.044 \\
\hline & NDLP & & & & 1 & 0.030 & -0.127 & 0.083 & -0.371 \\
\hline & NDS & & & & & 1 & 0.495 & 0.063 & -0.139 \\
\hline & NIFH & & & & & & 1 & 0.421 & -0.228 \\
\hline & NPS & & & & & & & 1 & -0.185 \\
\hline & SW & & & & & & & & 1 \\
\hline \multirow{8}{*}{ P11 } & NFP & 1 & $0.592^{*}$ & $0.633^{*}$ & -0.200 & 0.045 & $0.441^{*}$ & 0.136 & 0.029 \\
\hline & NDP & & 1 & 0.087 & 0.070 & 0.088 & 0.279 & 0.156 & -0.241 \\
\hline & NLP & & & 1 & -0.137 & 0.013 & 0.327 & 0.289 & 0.094 \\
\hline & NDLP & & & & 1 & -0.306 & 0.360 & 0.221 & -0.244 \\
\hline & NDS & & & & & 1 & 0.111 & -0.278 & 0.056 \\
\hline & NIFH & & & & & & 1 & $0.424^{*}$ & -0.321 \\
\hline & NPS & & & & & & & 1 & -0.044 \\
\hline & SW & & & & & & & & 1 \\
\hline \multirow{8}{*}{ P12 } & NFP & 1 & $0.774_{*}^{*}$ & $0.625^{*}$ & -0.370 & 0.336 & 0.032 & 0.067 & -0.217 \\
\hline & NDP & & 1 & $0.502^{*}$ & -0.053 & 0.290 & 0.000 & 0.165 & -0.211 \\
\hline & NLP & & & 1 & -0.163 & 0.196 & 0.376 & 0.277 & 0.164 \\
\hline & NDLP & & & & 1 & -0.027 & 0.042 & 0.133 & -0.097 \\
\hline & NDS & & & & & 1 & -0.380 & 0.173 & 0.177 \\
\hline & NIFH & & & & & & 1 & 0.117 & 0.030 \\
\hline & NPS & & & & & & & 1 & 0.412 \\
\hline & SW & & & & & & & & 1 \\
\hline
\end{tabular}


*. Correlation is significant at the 0.05 level (1-tailed).

**. Correlation is significant at the 0.01 level (2-tailed).

$N F P=$ Number of fruits per plant,$N D P=$ Number of damaged pods per plant, $N L P=$ Number of leaves per plant, $N D L P=$ Number of damaged leaves per plant, $N D S=$ Number of Dysdercus superstitiosus per plant $N I F H=$ Number of insect feeding holes per plant, NPS $=$ Number of Podagrica spp. per plant and SW $=$ Seed yield per plant

Table 3 shows the correlation between seed yield and the other traits among the West African okra genotypes. In genotype 6, a significant and positive correlation exists between number of fruits per plant, number of leaves per plant and seed yield. This implies that more leaves production will result in increased photosynthetic capacity of the plant which will invariably lead to more fruit production which will result in increased seed yield since more fruits will contain more seeds. A significant and positive correlation exists between number of fruits per plant and number of damaged pods in genotype 1. This implies that higher number of fruits will result in increased number of damaged pods. A positive and significant correlation exists between number of insect feeding holes and number of Podagrica specie which implies that the greater the number of Podagrica specie, the more the number of insect feeding holes that will be observed.

A negative correlation exists between number of damaged leaves, number of damaged pod and seed yield. This implies that greater number of damaged leaves and damaged pods will result in reduced seed yield. A significant and positive correlation exists between number of fruits and number of damaged pods implying that the greater the number of fruits per plant, the more the number of damaged pods that will be recorded. A negative and significant correlation exists between number of Dysdercus spp. and seed yield in genotype 5. This implies that higher number of Dysdercus spp. will result in reduced seed yield. Number of damaged pods had a positive correlation with number of Dysdercus spp. implying that higher population of Dysdercus spp. will result in increased number of damaged pods. A positive and significant correlation between number of fruit and number of leaves per plant in genotype 8 implies that the greater the photosynthetic capacity of the plant will likely result in increased number of fruits.

A positive correlation between number of damaged pods and number of Dysdercus spp. Indicates that the greater the population of Dysdercus spp., the higher the number of damaged pods recorded. A negative correlation between number of damaged leaves, number of Dysdercus spp., number of insect feeding holes, number of Podagrica spp. and seed yield implies that reduced number of damaged leaves, reduced population of Dysdercus spp. and Podagrica spp. and reduced number of insect feeding holes recorded will likely result in increased seed yield. A significant and positive correlation exist in number of fruits, number of damaged pods and number of leaves in genotype 12. This implies that increased number of leaves will likely result in increased number of fruits and this will lead to increased number of damaged pods. A positive correlation between number of fruits and number of Dysdercus spp.; and number of damaged pods and number of Dysdercus spp. Implies that more fruits attract higher population of Dysdercus spp. and this will likely result in increased number of damaged pods which will invariably result in reduced seed yield.

Table 4:- Biochemical Composition of the West African Okra Genotypes

\begin{tabular}{lllllll}
\hline Genotype & \% Tannin & \% Saponin & \% Alkaloid & \% Cardenoloids & \% Steroid & \% Terpenes \\
\hline $\mathrm{P}_{1}$ & 0.069 & 0.430 & 1.150 & 0.230 & 0.210 & 0.043 \\
$\mathrm{P}_{5}$ & 0.064 & 0.390 & 1.060 & 0.180 & 0.130 & 0.038 \\
$\mathrm{P}_{6}$ & 0.079 & 0.550 & 2.150 & 0.670 & 0.390 & 0.055 \\
$\mathrm{P}_{8}$ & 0.860 & 0.580 & 2.260 & 0.750 & 0.440 & 0.058 \\
$\mathrm{P}_{11}$ & 0.094 & 0.640 & 2.340 & 0.840 & 0.520 & 0.062 \\
$\mathrm{P}_{12}$ & 0.076 & 0.470 & 1.180 & 0.270 & 0.160 & 0.049. \\
\hline
\end{tabular}

Table 4 shows the biochemical composition of the genotypes of West African Okra. The biochemical analysis indicates the presence of tannin, saponin, alkaloid, cardenoloids, steroids and terpenes in the genotypes. Genotype 5 recorded the least percentage of all the chemical constituents of mean $0.064 \%, 0.390 \%, 1.060 \%$, $0.180 \%, 0.130 \%$ and $0.038 \%$ of the chemicals respectively. The highest percentage of the chemicals was recorded in genotype 11 of mean $0.094 \%, 0.640 \%, 2.340 \%, 0.840 \%, 0.520 \%$ and $0.062 \%$ respectively. The biochemical analysis clearly shows why genotype 11 was more resistant to both Podagrica spp. and Dysdercus superstitiosus attack than the other genotypes.

From this analysis, it was revealed that the high yielding genotype recorded a reduced population of Podagrica spp. and Dysdercus spp. The results of the biochemical analysis carried out on the genotypes revealed that the genotypes with an elevated level of the bioactive ingredient attracted less number of insect which acted as deterrents to the insects by resisting such insects from feeding and ovipositioning on them compared to the ones with low level of the bioactive ingredients. The biochemical analysis revealed the presence of tannin, saponin, alkaloid, cardenoloid, steroid, and terpenes in the genotypes. The genotype with 
high percentage of these compounds recorded a lower insect population compared to the ones that contained a lower percentage of these compounds. This finding agrees with the findings of Smith (1989) that allelochemical compounds acting as deterrent are frequently alkaloids, favonoids, terpenes, lactones and phenols. Similarly, Lale and Efeovbokhan(1991) and Epino and Rejesus (1983) reported that the presence of harmful chemical compounds in the seed testa of a resistant cowpea variety prevented them from being attacked by insects.

Palaniappan and Annadurai (1999) and Farlex (2004) reported that pest repellent plants may serve as an alternative method in controlling pests in organic agriculture and thus avoid the use of synthetic pesticides. Supawan and Ranamukhaarachchi (2006) also reported the potential of integrating specific pest repellent plants in intercropping to reduce populations of specific insect pests and percentage damage and to increase the quality and marketable yield of Chinese kale, Brassica oleracea.

\section{Conclusion}

From the study it could be concluded that the resistant varieties will reduce dependency on pesticides and will save the much needed money currently being used for the purchase of chemical pesticides. Also the use of resistant varieties will eliminate the consumption of chemical pesticide which are left as residues in farm produce; also reduce the damage often done to the environment as a result of pollution through the use of pesticide. From this study, the three genotypes (NGAE-96-0067, NGEA-96-0123 and CEN 010) could be recommended to farmers due to their high fruit yield in spite of insect attack.

\section{References}

[1]. Ariyo O.J. 1993. Genetic diversity in West African Okra, Abelmoschus callei (A. Chev) Stevels multivariate analysis of morphological and agronomic characteristic. Genetic Res. And crop Evol. 40:25-32.

[2]. Awasthi, M.D. 2001. Pesticide residues infruit and vegetables. In: Parvatha Reddy, P., A. Verghese and N.K. Krishna Kumar(eds.), Integrated Pest Management in Horticultural Ecosystems, pp: 263-78. Capital Publishing Company, New Delhi, Indisa.

[3]. Chaudhary, H.R and Deedhack, L.N. 1989. Incidence of insects attack on okra and the avoidable losses by them. Annals of aridzone 28:305-307.

[4]. Epino, P.B. and Rejesus, B.M. 1983. Physico- chemical properties of mungbean, Vigna radiata (wilkzec)L. Philippine Entomologist. 6:607-620

[5]. FAO. 1972. Food Composition Table for use in Africa sited from H.D. Tindall. Vegetables in the Tropics Macmillan Press Ltd. Hong Kong Pp 335.

[6]. Farlex, 2004. Integrated Pest Management. http:// encyclopedia.thefreedictionary.com (Accessed November 11, 2004).

[7]. Harris, J. and Dent, D. 1999. Priorities in Bio- pesticide R and D in Developing Countries.http:// www. Biopesticide.org/ Reports/ Priorities- BP. Htm (Accessed December 8, 2003).

[8]. Hill, D.S. and Waller, J. 1994. Pests and Diseases of Tropical Crops. Cambridge University Press, London. pp. 101-134.

[9]. Kumar, N.K. and Moorthy, P.N. 2001. Integrated Pest Management of insects damaging solanaceous vegetables. In: Parvatha Reddy, P., A. Verghese and N.K. Krishna Kumar(eds.), Integrated Pest Management in Horticultural Ecosystems, pp: 34-45. Capital Publishing Company, New Delhi, India.

[10]. Lale, N.E.S. and Efeovbokhan, S.O 1991. Resistance status of new cowpea cultivars to a storage insect pest, Callosobruchus maculatus. Post harvest Biology and Technology, 1: 181-186

[11]. Oerke, E.C., Deline, H., W., Schonbeck, F. and Weber, A. 1994. Crop production and Crop protection: Estimated losses in major food and cash crops. Elsevier, Amsterdam, Netherlands. 808pp.

[12]. Palaniappan, S.P. and Annadurai, K. 1999. Organic Farming:Theory and Practice. Scientific Publishers, Jodhpur.

[13]. Smith, C.M. 1989. Plant Resistance to insects: A fundamental approach, John ijl and Sons, New York.

[14]. Stevels, J.M.C. 1988. Une nouvelle combinaison dans Abelmoschus medik, un gombo d' Afrique de L' Quest et centrale Bull. Mus. Hist. Natural, Paris, 4 serie, 10, section B, Adansonia, No 2:137-144.

[15]. Sun, B., Liang, S.B. and Zhao, W.X. 2000. Outbreak of the Soybean aphid in Suihua prefecture in 1998 and its control Strategies. Soybean bull 1:5

[16]. Tindall, H.D. 1983. Vegetables in the Tropic. Oxford University Press, London. pp.90-145.

[17]. Visser, J.H. 1986. Host odour perception in phytophagus insects. Ann. Rev Entomol 31: $121-144$.

[18]. Zehnder,G.,2004. Integrated PestManagement in the Home Vegetable. Garden.http://www.clemson.edu/scg/ipm/hmeveg.htm H Trap\%20 Plants. 